\title{
KNOWLEDGE OF HCV INFECTION AMONG NURSING STUDENTS OF THE MEDICAL COLLEGE OF BITOLA
}

\author{
Viktorija PRODANOVSKA-STOJČEVSKA ${ }^{1}$, Rozalinda ISJANOVSKA ${ }^{2}$, and \\ Elizabeta POPOVA-RAMOVA ${ }^{1}$
}

\begin{abstract}
Medical College, University St. Kliment Ohridski, Bitola1 , Faculty of Medicine, Sts. Cyril and Methodius University,
\end{abstract} Skopje ${ }^{2}$, Macedonia

Received in July 2009

Accepted in October 2009

\begin{abstract}
Healthcare workers are at risk of occupationally-acquired viral infections such as human immunodeficiency virus (HIV), hepatitis B (HBV), and hepatitis C (HCV). HCV is parenterally transmitted and has been found in every part of the world. This cross-sectional study was conducted to establish the awareness and attitude about HCV infections among 210 full-time and part-time nursing students of the Medical College in Bitola, Macedonia 'from May to June 2009. For this purpose we used a self-administered questionnaire which consisted of three parts. The first included demographic data, the second included questions about causes of infection, mode of transmission, symptoms, acute and chronic hepatitis, and prevention, and the third questions about students' attitude toward patients with suspect or confirmed HCV infection. Full-time students showed higher HCV awareness (84\%) than part-time students (69\%). $58 \%$ of the full-time and $79 \%$ of the part-time students said they would not avoid professional contact with suspect or HCV infected patients. Our study has shown that even though both groups of students have a sufficient knowledge about $\mathrm{HCV}$ to face future challenges, they need further education on the subject. Practical recommendations would help to reduce stigmatising behaviour still further.
\end{abstract}

KEY WORDS: bloodborne pathogens, healthcare workers, occupational risk

Since the discovery of the hepatitis $\mathrm{C}$ virus (HCV) in 1989 and its identification as one of the leading causes of chronic liver disease with life-threatening sequelae such as end-stage cirrhosis and liver cancer (1), questions have been raised about the burden of disease caused by the virus (2). Data on the burden of hepatitis $\mathrm{C}$ in Europe are scarce, outdated or inconclusive, and our study indicates that hepatitis $\mathrm{C}$ is still a neglected disease in many countries (2). $\mathrm{HCV}$ is parenterally transmitted and has been found in every part of the world $(3,4)$.

Healthcare workers run the occupational risk of infection with human immunodeficiency virus (HIV), hepatitis B (HBV), and hepatitis C (HCV) (5). Infection is most often bloodborne through broken skin or mucous membrane (6). The risk of infection after an injury is about $33 \%$ for $\mathrm{HBV}, 3.3 \%$ for $\mathrm{HCV}$, and $0.33 \%$ for HIV (7).

The prevalence of anti-HCV in healthcare workers is $1 \%$ to $5 \%(8)$. The occupational risk of $\mathrm{HCV}$ transmission is real and is best controlled by rigorous universal infection precautions against nosocomial $\operatorname{HCV}$ infection $(9,10)$.

In Birmingham teaching hospitals, respondents to a questionnaire exhibited substantial lack of knowledge about HBV, HCV, and HIV transmission risks (11). A study by Janjua et al. (12) with healthcare workers in Pakistan has shown that education about infections leads to improved use of universal precautions against bloodborne pathogens. As students of medicine or 
nursing as also exposed to the risk of contracting bloodborne infections, education on infection control should also include them (13).

According to several studies of clinical practice, patients infected with HBV and HCV suffer from some level of stigmatisation and avoidance of care $(14,15)$.

The aims of this study were to establish students' knowledge about HCV infections, risk behaviour, modes of transmission and prevention and to evaluate their attitude toward patients with suspect or confirmed $\mathrm{HCV}$ infection.

\section{SUBJECTS AND METHODS}

Our cross-sectional study included 210 senior nursing students - prospective health-care workers - of the Medical College in Bitola and took place from May to June 2009. Additionally, we wanted to compare 110 full-time students, who attended all classes for six semesters, and 100 part-time students, who already worked as nurses (with secondary schools diplomas) and who decided to continue education and obtain a bachelor's degree. Both groups of students had the identical programme, but the part-time students were relieved of some of the classroom obligations. All participating students were about to complete their studies (few exams away) and to receive a bachelor's degree in nursing.

We used a non-standardised, anonymous, selfadministering questionnaire that consisted of three parts: 1) socio-demographic data;2) knowledge about HCV infections; and 3) students' attitude toward HCV-positive patients.

The first part included data about the age, sex, years of study, type of study, secondary education, and employment.

To make processing easier, the second part included a set of YES/NO questions about viral pathogenesis, modes of transmission, risk factors (blood transfusion before 1995, surgical or gynaecology intervention, dental intervention, tattoos, piercing, intravenous drug users, haemodialysis, and occupational exposure), symptoms, diagnosis, and infection prevention.

The third part included questions about attitudes toward persons who might or are infected with $\mathrm{HCV}$.

The collected data are shown in tables and figures. Statistical significance was tested using the chi-square test and the $t$-test.

\section{RESULTS}

Table 1 shows the socio-demographic data for fulltime and part-time students. The groups significantly differed in age [full-time $=(21.9 \pm 2.1)$ years; parttime $=(33.8 \pm 7.8)$ years, $\mathrm{P}<0.001$, Table 1$]$.

Table 1 Student demographic data

\begin{tabular}{lcc}
\hline Student data & Full-time & Part-time \\
\hline Male & 23 & 11 \\
Female & 87 & 89 \\
Employed & & 90 \\
Unemployed & 110 & \\
$\begin{array}{l}\text { Average age } \pm \text { SD / } \\
\text { years (range) }\end{array}$ & $21.9 \pm 7.82$ & $33.8 \pm 2.07^{*}$ \\
$\begin{array}{l}\text { Secondary school with } \\
\text { nursing programme }\end{array}$ & 73 & 89 \\
$\begin{array}{l}\text { Secondary school with } \\
\text { other programmes }\end{array}$ & 25 & 7 \\
Other & 12 & 4 \\
\hline
\end{tabular}

*difference statistically significant at $P<0.001$

\section{Knowledge about HCV infection}

Full-time students had a greater score of true answers about general knowledge of HCV infection (viral pathogenesis, symptoms, diagnosis and infection prevention) than part-time students ( $84 \%$, vs. $69 \%$; $\mathrm{P}<0.01)$. Pearson's chi-square test confirmed the dependence between the full-time/part-time status and true $\operatorname{score}\left(\chi^{2}=59.84, \mathrm{P}<0.001, \mathrm{Df}=1\right)$.

Figure 1 shows that full-time students scored significantly higher than part-time students in the questionnaire section on infection risk factors [means: (7.7 \pm 1.6$)$ vs. (6.9 \pm 2.7$)$, respectively; $\mathrm{P}=0.0089]$.

As for the questions about HCV transmission modes, $84 \%$ of the full-time students and $80 \%$ of

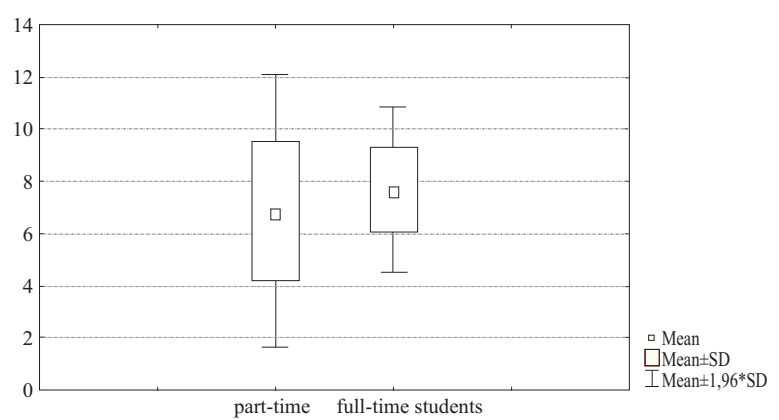

Figure 1 Students' score of correct answers about HCV infection risk factors by group 
the part-time students answered correctly, and the difference was not significant (Figure 2).

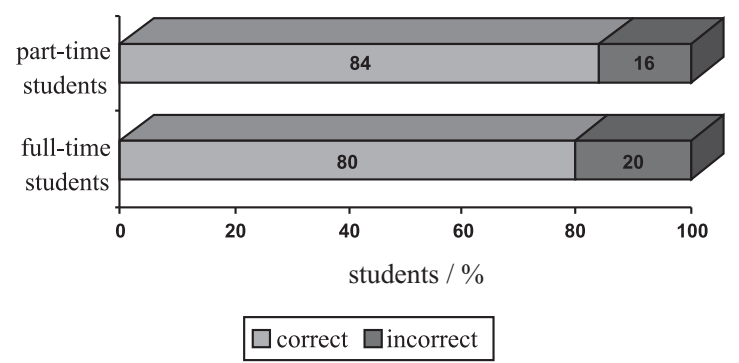

Figure 2 Percent of students with correct and incorrect answers on modes of HCV transmission by groups

\section{Students' attitude toward suspect or infected HCV patients}

Our results show that $58 \%$ full-time and $79 \%$ parttime students do not avoid professional contact with suspect infected HCV patients, while $65 \%$ full-time and $80 \%$ part-time students do not avoid any kind of contact with them $(\mathrm{P}<0.001)$. Pearson's chi-square test confirmed the dependence between the full-time/parttime status and willingness to contact $\mathrm{HCV}$ patients (Pearson's $\chi^{2}=16.409, \mathrm{P}<0.001, \mathrm{Df}=1$ ).

\section{DISCUSSION AND CONCLUSION}

Students in this cross-sectional study were mostly young women, which is usual for a nursing school. As expected, most of the students had completed a secondary school with a medical programme.

As we said earlier, there full-time students were significantly older than part-time students as they immediately move on to college from the secondary school and the latter study with work. A research conducted in Israel showed a high level of knowledge among 180 nurses about blood-borne infections and better knowledge of HBV than HCV infection (15).

While both our groups have generally shown a high level of knowledge about HCV infection, fulltime students scored significantly higher $(89 \%$ and $64 \%$ correct answers, respectively). We believe that this is the result of regular attendance to theoretical and practical classes.

Both of our groups showed sufficient knowledge about the risk factors ( $85 \%$ and $76 \%$ ). These results are similar to the findings for the University of Karachi students (95\% and $67 \%$ ) (16).
Both our groups of students also showed a high level of knowledge about HCV transmission. This is because the full-time students have sufficient knowledge about $\mathrm{HVC}$ infection and the part-time students pay more attention to the mode of transmission to protect themselves. Again, these results are similar to the Karachi University findings (98 \%) (16).

One of the aims of this study was to see students' attitude toward patients with suspect or confirmed $\mathrm{HCV}$ infection; $38.6 \%$ full-time and $20.5 \%$ part-time said they avoided contact with these patients. This is most probably because the full-time students are more aware of $\mathrm{HCV}$ infection risks than the part-time students. In Israel, the percentage of nurses who shun contact (77.3 \%) with HIV, HBV, and HCV infected patients is much higher (15), but this may mostly be related to the fear of HIV/AIDS (17). These results however confirm that $\mathrm{HCV}$ patients are stigmatised (18-21) and that this kind of intolerance leads adversely affects the quality of patient care (22).

Our study has shown that even though both groups of students have a sufficient knowledge about HCV, they need further education on the subject. This is particularly true for the part-time students, who need more hours in the classroom.

Stigmatising attitude towards infected $\mathrm{HCV}$ patients should be addressed by focusing on practical recommendations for infection prevention.

All things considered, however, our nursing students are prepared for the challenges that come with profession.

\section{Acknowledgement}

We wish to thank Professor Rozalinda Isjanovska, epidemiologist of the Skopje University School of Medicine for helping us prepare the student questionnaire. Professor Isjanovska is the president of the HEPTA Association, a unique non-governmental organisation dealing with hepatitis $\mathrm{C}$ infections.

\section{REFERENCES}

1. Lauer GM, Walker BD. Hepatitis C virus infection. N Engl J Med 2001;345:41-52.

2. Mühlberger N, Schwarzer R, Lettmeier B, Sroczynski G, Zeuzem S, Siebert U. HCV-related burden of disease in Europe: a systematic assessment of incidence, prevalence, morbidity, and mortality. BMC Public Health 2009;9:34.

3. Purcell RH. Hepatitis C virus. In: Webster RG, Granoff A, editors. Encyclopedia of Virology. London: Academic Press Ltd; 1994. p. 569-74. 
4. World Health Organization (WHO). Hepatitis C 1997 [displayed 22 March 2010]. Available at: http://www.who. int/inf-fs/en/fact164.html.

5. Scoular A, Watt AD, Watson M, Kelly B. Knowledge and attitudes of hospital staff to occupational exposure to bloodborne viruses. Commun Dis Public Health 2000;3:2479 .

6. Royal College of Nurses. Universal precautions. Nurs Stand 1997;11:32.

7. UK Health Departments. Guidance for clinical health care workers: protection against infection with blood-borne viruses. Recommendations of the Expert Advisory Group on AIDS and the Advisory Group on Hepatitis 1998 [displayed 22 March 2010]. Available at: http://www.dh.gov.uk/prod consum_dh/groups/dh_digitalassets/@dh/@en/documents/ digitalasset/dh_4014474.pdf.

8. World Health Organization (WHO). Hepatitis C, 2002 [displayed 22 March 2010]. Available at: http://www.who. int/csr/disease/hepatitis/Hepc.pdf.

9. Memon MI, Memon MA. Hepatitis C: an epidemiological review. J Viral Hepatol 2002;9:84-100.

10. Schvarcz R, Sönnerborg A, Johansson B, Nyström B. Nosocomial transmission of hepatitis $\mathrm{C}$ virus. Infection 1997;25:74-7.

11. Stein AD, Makarawo TP, Ahmad MF. A survey of doctors' and nurses' knowledge, attitudes and compliance with infection control guidelines in Birmingham teaching hospitals. J Hosp Infect 2003;54:68-73.

12. Askarian M, Honarvar B, Tabatabaee HR, Assadian O. Knowledge, practice and attitude towards standard isolation precautions in Iranian medical students. J Hosp Infect 2004;58:292-6.

13. Janjua NZ, Razaq M, Chandir S, Rozi S, Mahmood B. Poor knowledge-predictor of nonadherence to universal precautions for blood borne pathogens at first level care facilities in Pakistan. BMC Infect Dis 2007;7:81.

14. Butt G. Stigma in the context of hepatitis C: concept analysis. J Adv Nurs 2008;62:712-24.

15. Kagan I, Ovadia KL, Kaneti T. Perceived knowledge of blood-borne pathogens and avoidance of contact with infected patients. J Nurs Scholarsh 2009;41:13-9.

16. Anjum Q, Siddiqui H, Ahmed Y, Rizvi SR, Usman Y. Knowledge of students regarding hepatitis and HIV/AIDS of a private medical university in Karachi. J Pak Med Assoc 2005;55:285-8.

17. Röndahl G, Innala S, Carlsson M. Nursing staff and nursing students' attitudes towards HIV-infected and homosexual HIV-infected patients in Sweden and the wish to refrain from nursing. J Adv Nurs 2003;41:454-61.

18. Cormier M. The role of hepatitis $\mathrm{C}$ support groups. Gastroenterol Nurs 2005;28(3 Suppl):S4-9.

19. Grundy G, Beeching N. Understanding social stigma in women with hepatitis C. Nurs Stand 2004;19:35-9.

20. Mohamed R, Desmond P, Suh DJ, Amarapurkar D, Gane E, Guangbi Y, Hou JL, Jafri W, Lai CL, Lee CH, Lee SD, Lim SG, Guan R, Phiet PH, Piratvisuth T, Sollano J, $\mathrm{Wu}$ JC. Practical difficulties in the management of hepatitis $\mathrm{B}$ in the Asia-Pacific region. $\mathrm{J}$ Gastroenterol Hepatol 2004;19:958-69.

21. Zacks S, Beavers K, Theodore D, Dougherty K, Batey B, Shumaker J, Galanko J, Shrestha R, Fried MW. Social stigmatization and hepatitis $\mathrm{C}$ virus infection. J Clin Gastroenterol 2006;40:220-4.

22. Kyle TV. The concept of caring: a review of the literature. J Adv Nurs 1995;21:506-14. 


\section{Sažetak}

\section{KOLIKO SU STUDENTI VIŠE MEDICINSKE ŠKOLE U BITOLI UPOZNATI S PROBLEMOM INFEKCIJE HCV-OM}

Zdravstveni su radnici izloženi profesionalnomu riziku od infekcije virusom humane imunodeficijencije (HIV-om), hepatitis B virusom (HBV-om) te hepatitis C virusom (HCV-om). HCV se prenosi parenteralno i ima ga posvuda u svijetu. Ovo smo presječno ispitivanje proveli da utvrdimo koliko su studenti za medicinske tehničare i sestre upoznati s infekcijom HCV-om i saznamo njihove stavove o tome. Ispitivanje je obuhvatilo 210 redovitih i izvanrednih studenata Visoke medicinske škole u Bitoli i trajalo je od svibnja do lipnja 2009. Za ispitivanje je rabljen opširan upitnik. Odgovori su pokazali da redoviti studenti imaju bolji uvid u predmet (s $84 \%$ točnih odgovora) od izvanrednih studenata (69\%). U pogledu stava prema pacijentima $58 \%$ redovitih i $79 \%$ izvanrednih studenata ne izbjegava dodir s pacijentima koji su inficirani HCV-om. Ispitivanje je pokazalo da su studenti iz obje skupine dovoljno upoznati s infekcijom HCV-om, rizičnim čimbenicima i načinom prijenosa, ali je potrebno to znanje nadograditi.

KLJUČNE RIJEČI: patogeni koji se prenose krvlju, profesionalni rizik, zdravstveni radnici

\section{CORRESPONDING AUTHOR:}

Viktorija Prodanovska-Stojčevska Ul. Prevalec 21, 7000 Bitola, Macedonia

E-mail:prodanovska@yahoo.com 